\title{
Narcyz w muzeum. Przygoda ponowoczesna
}

Iwona Kurz

TEKSTY DRUGIE 2020, NR 4, S. 37-49

DOI: 10.18318/td.2020.4.3 | ORCID: 0000-0001-7180-8670

\section{Ulica jednokierunkowa}

Powtarzającym się elementem ekspozycji nowych muzeów narracyjnych jest „ulica”. Głośne przykłady to $\mathrm{Mu}$ zeum Powstania Warszawskiego (otwarte w 2004 roku), Muzeum Historii Żydów Polskich POLIN (2013), Muzeum II Wojny Światowej w Gdańsku (2017), ekspozycja Europejskiego Centrum Solidarności (2014) czy wystawa Światto historii. Górny Ślask na przestrzeni dziejów w nowej siedzibie Muzeum Śląskiego (2015). Są to przykłady głośne, ponieważ muzea te konsekwentnie proponowały nowe narracje na temat istotnych kontekstów czy wydarzeń historycznych, silnie uwikłane w dyskusję o pamięci i tożsamości. Jako takie stały się także centrum ostrych sporów politycznych.

Ich tłem była - i jest - dyskusja o polityce historycznej, jej zasadniczej celowości i jej szczegółowych celach'.

1 Por. m.in. Polityka historyczna. Historycy - politycy - prasa, red. A. Panecka, Muzeum Powstania Warszawskiego, Warszawa 2005; Pamięć i odpowiedzialność, red. R. Kostro, T. Merta, Ośrodek Myśli Politycz-
Iwona Kurz - dr hab. prof. uczelni, pracuje w Instytucie Kultury Polskiej Uniwersytetu Warszawskiego.

Zajmuje się historią i teorią kultury nowoczesnej w perspektywie wizualnej, w tym zagadnieniami pamięci oraz ciała i gender. Redaguje pismo „Widok. Teorie i Praktyki Kultury Wizualnej" (www.pismowidok.org). Więcej: http://ikp.uw.edu.pl/ dr-hab-iwona-kurzl. Kontakt: i.kurz@ uw.edu.pl 
Otwarcie Muzeum Powstania Warszawskiego w sierpniu 2004 roku, z okazji sześćdziesiątej rocznicy wybuchu powstania, było tu punktem zwrotnym. Polityka historyczna stała się wówczas częścią programu politycznego Prawa i Sprawiedliwości, a Muzeum uznano za pierwszą zapowiedź jej instytucjonalizacji ${ }^{2}$. Częścią tego procesu była nie tylko sama ekspozycja - po dekadach oddająca uznanie uczestnikom powstania i przywracająca to wydarzenie pamięci zbiorowej - ale też zaproponowana przez jej twórców reinterpretacja historiozoficznego sensu powstania, które w dialektycznym spotkaniu z sierpniem 1980 roku pozwoliło na dopełnienie polskiego losu, zakleszczonego między Niemcami a Rosją, w niepodległej już Polsce ${ }^{3}$.

Polityka historyczna nie jest tematem tego artykułu; przywołuję ją jednak jako istotne tło dla namysłu nad sposobem działania muzeów narracyjnych czy, precyzyjniej, historycznych muzeów narracyjnych. Trzecia bowiem kwestia związana z Muzeum Powstania Warszawskiego, po nowej opowieści o tym wydarzeniu i wpisaniu go w zadania polityki historycznej państwa, to zastosowane w tym procesie narzędzia, czyli medialny charakter samej ekspozycji oraz towarzyszący jej układ instytucjonalny wiążący działania badawcze z edukacyjnymi, popularyzacyjnymi, a nawet komercyjnymi.

Istotny jest też sam punkt wyjścia do dyskusji o polityce historycznej - założenie jej inicjatorów i propagatorów ${ }^{4}$, że po 1989 roku dokonało się w Polsce wymazanie z debaty publicznej kwestii historii i pamięci, zastąpionej bądź przez hasła aspiracyjne związane z transformacją („Wybierzmy przyszłość” Aleksandra Kwaśniewskiego lub łączący wiele środowisk politycznych „kierunek na Zachód”), bądź przez historię krytyczną konstruującą „wspólnotę wstydu". Przekonanie, że po zmianie ustrojowej wreszcie można mówić prawdę o historii, dla niektórych uczestników życia publicznego oznaczało

nej, Kraków 2005; R. Traba Polityka wobec historii, "Teksty Drugie” 2010 nr 1/2, S. 300-319; Historycy i politycy. Polityka pamięci w III RP, red. P. Skibiński, T. Wiścicki, M. Wysocki, DiG, Warszawa 2011.

2 Por. M. Łuczewski Kontrrewolucyjne pojęcie. „Polityka historyczna” w Polsce, "Stan Rzeczy” 2016 nr 10, s. 221-257.

3 Por. D. Gawin Wstęp, w: Spór o Powstanie. Powstanie Warszawskie w powojennej publicystyce polskiej 1945-1981, red. D. Gawin, Muzeum Powstania Warszawskiego, Warszawa 2004.

4 Było to środowisko związane z Warszawskim Klubem Krytyki Politycznej, a potem z „Teologią Polityczną", m.in. Marek Cichocki, Lena Dąbkowska-Cichocka, Dariusz Gawin, Magdalena Gawin, Dariusz Karłowicz, Robert Kostro, Paweł Kowal, Tomasz Merta. 
bowiem, że teraz już można publicznie mówić o bezsensie, a nawet zbrodniczości powstania warszawskiego, poza uwikłaniem w uznanie racji władzy komunistycznej. Z perspektywy „muzealników”, jak zaczęto nazywać osoby zajmujące się koncepcją i budową Muzeum, wreszcie można było - i należało - mówić nie tylko o złożonej sytuacji geopolitycznej, co dotąd było cenzurowane $^{5}$, ale także o głębokim sensie politycznym i moralnym sierpnia 1944 roku. Ten sens polityczny nie wyczerpywał się jedynie w interpretacji historii - był koniecznym wymiarem budowania wspólnoty politycznej dzisiaj. Polityka historyczna ma swoje cele zewnętrzne, związane z przedstawieniem własnego punktu widzenia i racji innym stronom, ale ma też cel wewnętrzny, wychowawczy, dotyczący kształtowania określonego wyobrażenia o tożsamości narodowej na podstawie wydarzeń z przeszłości.

Temu przekazowi siłę nadaje określona medialna forma, którą gdzie indziej już nazwałam muzeosensorium ${ }^{6}$. W największym skrócie polegałoby to na tworzeniu przestrzeni muzealnej jako środowiska doświadczenia ${ }^{7}$ jako rekonstrukcji rzeczywistości historycznej pozwalającej zwiedzającym na zanurzenie się w niej. Osiąga się to za pomocą środków wielomedialnych, przekazów apelujących do różnych zmysłów jednocześnie i do każdego z nich osobno. Opis, obraz, film, komentarz audialny, nagrania dźwięków naturalnych oraz podkładu muzycznego i piosenek, przyciski uruchamiające aplikacje, ruch, wymagający niekiedy wykonywania czynności nietypowych dla tradycyjnych przestrzeni muzealnych - np. schylania się, przechodzenia przez wąskie przejścia, zaglądania w zakamarki etc. - angażują oko, ucho i całe ciało ${ }^{8}$. Nie jesteśmy w muzeum wobec obiektu, ale w muzeum jako metaobiekcie: spektakularnej kapsule czasu.

5 Stąd wystawa zaczyna się od wybuchu wojny jako w istocie czwartego rozbioru Polski.

6 Por. I. Kurz Le Musée de l'insurrection de Varsovie: muséographie, muséophotie, muséosensorium, w: Muséographie des violences en Europe centrale et ex-USRR, red. D. Bechtel, L. Jurgenson, Editions Kimé, Paris 2016.

7 Por. przegląd dyskusji na temat muzeum jako przestrzeni doświadczenia w książce Anny Ziębińskiej-Witek Historia w muzeach. Studium ekspozycji Holokaustu, Wydawnictwo UMCS, Lublin 2011, s. 42-51.

8 Por. opis na stronie Muzeum Powstania Warszawskiego: „W niepowtarzalny sposób zaprojektowana ekspozycja muzealna oddziałuje obrazem, światłem i dźwiękiem. Aranżacja wnętrza i wykorzystanie efektów multimedialnych przybliżają powstańczą rzeczywistość. Głównymi elementami wystawy są zdjęcia w wielkich formatach, monitory i komputery. Wytyczona trasa przedstawia chronologię wydarzeń i prowadzi przez poszczególne sale tematyczne. Zwiedzający poruszają się w scenerii sprzed siedemdziesięciu lat, chodzą po granitowym bruku wśród 
Jej zastosowanie ma swoje konsekwencje, niedające się zredukować do jedynie narzędziowego użycia. Nigdy dość przypominania, że „środek przekazu sam jest przekazem"', jak pisał na początku lat 6o. ubiegłego stulecia Marshall McLuhan. Nie bez powodu jest on jednak nazywany „prorokiem ery elektronicznej"10, ponieważ w epoce telewizyjnej dostrzegał przemiany, które widoczne czy oczywiste stały się dopiero w epoce informatycznej. Jedną z nich jest przejście od przyczyno-skutkowej logiki pisma i druku oraz porządku "następstwa zjawisk” do „świata struktury i konfiguracji”, związane również z dowartościowaniem innych zmysłów niż wzrok, rozumiany tu zresztą głównie jako instrument lektury.

„Ulica” w muzeum jest i przykładem, i metaforą tego procesu. Ulica okupowanej Warszawy, ulica Warszawy w dwudziestoleciu, ulice okupowanych miast Europy, wewnętrzna uliczka w stoczni - wszystkie one wzywają do spaceru. Konfiguracyjny charakter tego doświadczenia podporządkowany jest jednak „kierunkowi zwiedzania”, znów - i dosłownie, i metaforycznie. Można się oczywiście zgubić lub zrezygnować ze zwiedzania „po kolei”, tym bardziej można się „urwać” działaniu zakładanego przekazu, niemniej jest on wpisany w ekspozycję. „Ulica” powinna dokądś prowadzić. Pytanie jednak, czy zawsze prowadzi tam, gdzie chcieliby jej projektanci.

\section{Przeżycie „materialne"}

Doświadczenie „ulicy” muzealnej jest szczególne, zarazem rozgęszczone i zagęszczone, co wynika z charakteru ekspozycji muzealnej, która jest w całości znacząca na poziomie metajęzyka: poszczególne znaki użyte są świadomie w pewnej konstrukcji. Potoczne doświadczenie uliczne polega na zderzeniu z wielością bodźców, z których nie wszystkie muszą być znaczące (weźmy choćby bodźce naturalne, związane z warunkami atmosferycznymi), ale nawet jeśli tak jest, to znaczą - osobno. Nie układają się w wypowiedź, choć mogą zostać w nią przetworzone. Zagęszczenie semiotyczne ulicy muzealnej dokonuje się w przestrzeni wytworzonej, wypełnionej bodźcami

gruzów niszczonej Stolicy. Sercem Muzeum jest stalowy monument, przechodzący przez wszystkie kondygnacje budynku", www.1944.pl/artykul/ekspozycja,450o.html (19.03.2020).

10 Por. np. omówienie recepcji McLuhana w K. Loska Dziedzictwo McLuhana - między nowoczesnościq a ponowoczesnościq̨, Rabid, Kraków 2001. 
zaprojektowanymi pod kątem przekazu określonych treści. Swoisty hiperrealizm, właściwy też, choć w dużo mniejszym stopniu, niektórym historycznym realizacjom filmowym, sprawia, że w przestrzeni ekspozycji pojawiają się obiekty tylko z epoki. Nie pojawia się zjawisko płynnego współwystępowania przedmiotów czy dokumentów o różnym designie, „starych” i „nowych". Nie tyle przedstawiają one, jaka ta epoka była, ile - jaka miała być. Na dodatek ich wybór i układ zwykle podporządkowane są tematowi lub tezie. I tak, na „ulicy okupowanej Warszawy” zobaczymy jednocześnie różne niemieckie obwieszczenia, ale nie będzie tam ogłoszeń komercyjnych. Warszawskie dwudziestolecie to z kolei przestrzeń wypełniona odezwami i plakatami ruchów politycznych wypowiadających się na temat miejsca Żydów w Polsce. Itd. Itd. Jednocześnie wszystko w tej przestrzeni staje się „jedyne": za całe miasto wystarczy - metonimicznie - jeden bunkier, jedna barykada, jeden kanał, jedna ławka czy lampa, jedno wnętrze...

Dodatkowym źródłem bodźców jest - przedstawienie w przedstawieniu - sama sytuacja zwiedzania. Z „ulicy” można wyjść: do toalety, do miejsc odpoczynku, do innych przestrzeni ("galerii”) zwiedzania; one również są oznaczone, podobnie jak gaśnice czy specjalistyczne termometry. Przede wszystkim jednak są inni „spacerowicze”, raz bliżej, raz dalej, niekiedy wręcz tłum, wpisani w ten sam kontekst znaczący - współcześni zwiedzający, którzy mają poczuć się jak „ówcześni”. Przeżycia są zatem intensywne, a zmysły pracują, bez względu na to, czy ktoś pozwala sobie na zanurzenie w wykreowanej rzeczywistości, czy jednak próbuje uciec od kakofonii doznań. Muzeum Powstania Warszawskiego, z jednej strony stosunkowo niewielkie, wręcz ciasne, z drugiej - właśnie gęste, neofickie w swoim użyciu bodźców w nowej formule muzealnej, dostarcza w tym względzie doświadczenia szczególnie intensywnego. Jego elementy możemy jednak wyraźnie zobaczyć w innych ekspozycjach, które również - przynajmniej w niektórych fragmentach zachęcają do tego, żeby się „wczuć”.

Przy namyśle nad istotą tego muzealnego doświadczenia nie można uniknąć pytania o materialność - oraz o obiekty. W kolejnym zwrocie muzealnym, lokalnie ogłoszonym po otwarciu nowej ekspozycji stałej Muzeum Warszawy, zadekretowano „powrót do rzeczy”. Główna część wystawy zatytułowana Rzeczy warszawskie ${ }^{11}$ skupia się na wybranych obiektach, które w efekcie

11 Zob. opis na stronie Muzeum: https://muzeumwarszawy.pl/wystawa-glowna-rzeczy-warszawskie/ (19.03.2020). Por. też dwugłos na temat wystawy: A. Zborowska Gabinety nieuchwytnych rzeczy, "Widok. Teorie i Praktyki Kultury Wizualnej” 2018 nr 20, www.pismowidok.org/pl/ 
zyskują wyróżniony status przedmiotu o szczególnym znaczeniu. W istocie jednak należy tu mówić o stałym napięciu między dowartościowaniem rzeczy - obiektu jako wnoszącego „aurę” w zdematerializowane doświadczenie cyfrowego świata - a chęcią muzeum, by atrakcyjnie konkurować z innymi spektaklami współczesności ${ }^{12}$.„Nowoczesność” poniosła porażkę w Muzeum Chopina, kiedy okazało się, że tablety starzeją się szybciej niż urządzenia, z którymi zwiedzający przychodzą do muzeum, a największe „hity” zwiedzania to jednak maska pośmiertna kompozytora i bukiecik jego ulubionych fiołków (wraz z zapachem).

Zasadniczo we wskazanych muzeach relacja zwiedzających z materią pozostaje w rodzaju dwutaktu właśnie. Z jednej strony tam, gdzie w grę wchodzi oryginalny obiekt historyczny, pozostaje on chroniony, zamknięty w gablocie, wyróżniony jako taki. Niekiedy jednak podobny status nadaje się też replikom. Z drugiej strony otwiera się przed zwiedzającymi liczne możliwości działania, dotykania, manipulowania; można coś przycisnąć, otworzyć, wyciągnąć, czasem wziąć ze sobą - jak „kartki z kalendarza” w Muzeum Powstania Warszawskiego, odbitki z prasy powstańczej lub drukarni żydowskiej, wszędzie ulotki. Status tych obiektów, pozornie oddanych we władanie zwiedzających, jest jednak dwuznaczny. Obiekty historyczne legitymizują je, wzmacniając wrażenie „historyczności” całej ekspozycji. Ponieważ wystawione są one na dotyk, zakłada się, że łatwo mogą ulec zniszczeniu, co jest kosztowne, więc podlegają innego rodzaju ochronie - zostają zalaminowane czy też zatopione w jakiegoś rodzaju substancji ochronnej, niczym smartfon w etui. Ich „koszt” jest czysto ekonomiczny, ale w użyciu uzyskuje również sankcję symboliczną związaną z kontekstem - ekspozycji poświęconej ważnemu wydarzeniu oraz użytą formą estetyczną.

W tym sensie przestrzeń muzeów narracyjnych oddaje - w mniejszym lub większym stopniu - hybrydyczny charakter przestrzeni, w jakiej funkcjonujemy, żyjąc jednocześnie w świecie wirtualnym (cyfrowym) i fizycznym. Zarazem jednak tę hybrydyczność ukrywa pod przykrywką laminatu, nadającego pozorną spójność całości przekazu. Obejmuje ona też wymiar

archiwum/2018/20-odmuzealnienie/gabinety-nieuchwytnych-rzeczy (19.03.2020); M. Wiśniewska Między materialnością rzeczy a obrazem miasta, „Widok. Teorie i Praktyki Kultury Wizualnej" 2018 nr 20, www.pismowidok.org/pl/archiwum/2018/20-odmuzealnienie/miedzy-materialnoscia-rzeczy-a-obrazem-miasta (19.03.2020).

12 Widzę to właśnie raczej jako stałe napięcie - niż sprzeczność, jak Anna Ziębińska-Witek Historia w muzeach..., s. 44-45. 
czasowy. Intencjonalnie chodzi o to, by to materialne, niemal namacalne doświadczenie muzealnego tu i teraz przenosiło nas w historię. Historia jest jednak zasysana w dziś. Po części tak miałoby być, jeśli ma być używana do konstruowania określonych postaw politycznych czy obywatelskich. Po części jednak proces ten może być sprzeczny z intencjami, wymykając się porządkowi narracji tożsamościowych. Dzieje się tak z dwóch powodów. Po pierwsze, łatwo wpisuje się w logikę towaru właściwą współczesności. Po drugie, opiera się on na przeżyciu podmiotowym, które łatwo wymyka się spod kontroli.

\section{Towar muzealny}

Zacznijmy od towaru. Określenie „ulica jednokierunkowa” użyte w śródtytule poprzedniej części zapożyczone jest z małej książeczki Waltera Benjamina. „Zdradza ona komponent materialistyczny [...] myśli Benjamina”, pisze Andrzej Kopacki, jej tłumacz, w dwustronicowym posłowiu ${ }^{13}$. Samo skojarzenie z tym tytułem może wydawać się powierzchowne, czysto brzmieniowe, ale ten „komponent materialistyczny” wskazuje na ważny, wskazany już, kontekst nowej muzeologii narracyjnej. Rozwija się ona z ciągłym towarzyszeniem dyskusji o (nie)materialności. „Spis treści Ulicy pełen jest towarów”, pisze chwilę wcześniej Kopacki, podkreślając sugestywną siłę, z jaką Benjamin zajmuje się materialnym detalem - „okruchem powszedniości, urojeniem z dzieciństwa, ulicznym szczegółem - zza którego przeziera siła filozoficznej diagnozy”.

W Pasażach ten sam rodzaj namysłu dotyczy rzeczy - i muzeum. Tu jednak kryje się on w montażu. Pojawia się we fragmentach, wypisach z lektur, dopiero domaga się interpretacji. Niemniej Benjamin bardzo wyraźnie podkreśla, że XIX-wieczne muzeum - zasadniczo u niego jest to muzeum sztuki - opiera się na tej samej logice towaru, która napędza kapitalizm. Muzea rozwijają się równolegle z wystawami światowymi ${ }^{14} \mathrm{i}$ domami towarowymi ${ }^{15}$, jak podkreśla. Są częścią tego, co Tony Bennett określił jako kompleks wystawienniczy, konieczne uzupełnienie Foucaultowskiego kompleksu karceralnego, które w istocie reguluje powszechny obieg wiedzy w społeczeństwie XIX-wiecznym:

13 A. Kopacki O czym jest „Ulica jednokierunkowa”?, w: W. Benjamin Ulica jednokierunkowa, przeł. A. Kopacki, Sic!, Warszawa 1997, s. 75. Dwa kolejne cytaty tamże.

14 W. Benjamin Paryskie pasaże I, <Ko, 20>, w: tegoż Pasaże, przeł. I. Kania, Wydawnictwo Literackie, Kraków 2005, s. 896.

15 W. Benjamin Zapiski i materiały, $\langle L$ 5, 5>, w: tegoż Pasaże, s. 453. 
Instytucje wchodzące w skład „kompleksu wystawienniczego" uczestniczyły w przekazywaniu obiektów i ciał z zamkniętych, prywatnych przestrzeni, w których je wcześniej pokazywano (lecz jedynie ograniczonej liczbie widzów) na coraz bardziej otwarte i publiczne areny, gdzie za pomocą reprezentacji, którym były podporządkowane, stawały się nośnikami zapisu i transmisji komunikatów władzy (ale innego typu) w obrębie całego społeczeństwa ${ }^{16}$.

Benjamin muzea sytuuje w „kategorii domów ze snów zbiorowości”" wskazując na konstytuującą je dialektykę między wychodzeniem z jednej strony „naprzeciw badaniu naukowemu”, a z drugiej - „sennej epoce złego smaku". I dalej, cytując książkę Sigfrieda Giediona Bauen in Frankreich (s. 36):

Wydaje się, że prawie każda epoka, stosownie do swego wewnętrznego nastawienia, opracowuje jakiś szczególny problem architektoniczny: gotyk - katedrę, barok - zamek, początek zaś XIX wieku, zwrócony wstecz w swym upodobaniu do przeszłości - muzeum. ${ }^{18}$

Wiek XXI potwierdza trwanie muzeum, tyle że jest to już inne muzeum - narracyjne i posługujące się nową formą utowarowienia. Nie dzieło sztuki jest tu przedmiotem wymiany, ale właśnie doświadczenie czy też przeżycie. „Domem ze snów zbiorowości” tworzącym właściwy dla niego kontekst jest natomiast galeria handlowa. Najpierw podobieństwa między muzeum a galerią potwierdza instytucja „sklepiku muzealnego", który ściśle wiąże niepowtarzalność przeżyć podczas zwiedzania ekspozycji $\mathrm{z}$ „ekskluzywnością" dostępnego asortymentu opatrzonego muzealnym logo. Zakup „solidarnościowego" albo „wojennego" czy „okupacyjnego” gadżetu nie powinien jednak przesłonić opisanego, konsumpcyjnego właśnie charakteru całości doświadczenia muzealnego, nastawionego na odbiór bodźców.

16 T. Bennett Kompleks wystawienniczy, przeł. M. Szubartowska, „Widok. Teorie i Praktyki Kultury Wizualnej" 2015 nr 10, www.pismowidok.org/pl/archiwum/2015/10-polski-wiek-xix/kompleks-wystawienniczy (19.03.2020). Dotyczy to całej części L Zapisków i materiałów. Cytat z fragmentu <L 1a, 2>, Pasaże, s. 452. Bauen in Frankreich, Baunen in Eisen, Bauen in Eisenbeton, Klinkhardt \& Biermann, Leipzig-Berlin 1928. 
W jednym i drugim przypadku pojawia się też „ulica”. „Wielka galeria handlowa jest jak miasteczko" - pisał Andrzej Leder niemal w przededniu otwarcia Muzeum Powstania Warszawskiego ${ }^{19}$. Sukces galerii handlowych w mieście tłumaczył, prawie w duchu „muzealników”, ,swoistym kalectwem pamięci jego mieszkańców. A może jeszcze bardziej - kalectwem przestrzeni miejskiej, która jest rusztowaniem dla pamięci"20. Co znamienne, w tym samym czasie, kiedy ulice (a ściślej - chodniki) polskich miast wykładano kostką Bauma, w galeriach handlowych i nowych muzeach pojawiała się kostka (jej imitacja) brukowa. Chodniki mogły być bieda-chodnikami, ,domy ze snów zbiorowości" domagały się estetyki historycznej, niezależnie od tego, czy handlowały towarami z dziś czy też z przeszłości.

\section{Podmiot narcystyczny}

Ponowoczesność kreuje podmiot narcystyczny - muzeum, o jakim tu mowa, na tym procesie pasożytuje i go wzmacnia. Christopher Lasch wprost pisze przecież o „kulturze narcyzmu”, ściśle zresztą wiążąc ją z wymiarem medialnym:

Żyjemy w kłębowisku obrazów i dźwięków, które rejestrują doświadczenie i odtwarzają je na nowo w zwolnionym tempie. Kamery i urządzenia nagrywające nie tylko kopiują doświadczenie, ale także zmieniają jego wartość, czyniąc ze współczesnego życia ogromną kabinę pogłosową i gabinet luster. Życie jawi się jako następstwo obrazów lub elektronicznych sygnałów, wrażeń nagrywanych i odtwarzanych przez urządzenia fotograficzne, filmy, telewizję i wysokiej klasy urządzenia elektroniczne. ${ }^{21}$

Lasch zwraca zatem uwagę na mnogość reprezentacji, które dotyczą ludzkiego - gatunkowo i jednostkowo - doświadczenia: zapisują je i zwrotnie przedstawiają na nowo. Impuls zapisu często wyprzedza samo doświadczenie lub wręcz je zastępuje. Każda prośba „uśmiechnij się" do kamery (o ile w ogóle

19 A. Leder Galeria handlowa, w: tegoż Przemiana mitów druga, czyli wojna o obrazy, Open, Warszawa 2004, s. 8. Tamże, s. 9. Pisałam też w tym kontekście o przekazie filmu Warszawa (2004) Dariusza Gajewskiego - o mieście "bez pamięci”.

21 Ch. Lasch Kultura narcyzmu. Amerykańskie życie w czasach malejących oczekiwań, przeł. G. Ptaszek, A. Skrzypek, Wydawnictwo Akademickie Sedno, Warszawa 2015, s. 73-74. 
jest konieczna), każda przybrana poza, każdy sfotografowany lub sfilmowany gest podejmowany jest z myślą nie o przeżyciu tu i teraz, ale o doświadczeniu oglądania i wspominania.W tym sensie doświadczenie medialne jest zawsze narcystyczne - i zawsze opóźnione, nawet w przypadku transmisji.

Ten wymiar medialny należy jednak pogłębić, przypominając raz jeszcze myśl McLuhana. Dla niego medium to właściwie każde "przedłużenie” nas samych - technologia lub urządzenie pozwalające na działanie zmysłów wykraczające poza "nagie" możliwości ludzkiego ciała. W efekcie każdego rodzaju zachwyt nad technologią, przywiązanie do przedmiotu lub gadżetu, który wspiera naszą komunikację ze światem, jest relacją samozwrotnie skierowaną na samego człowieka ${ }^{22}$.

Podobnie muzeum kreuje bardzo szczególną przestrzeń dla projekcji pamięci. Wymaga zaangażowania ciała widzów, stwarzając - w całości ekspozycji, jak w przypadku Muzeum Powstania Warszawskiego, lub w jej częściach - okazję, by poczuć się jak bohater z epoki. Elementy składające się na muzeosensorium generują potencjał do aktywnego przebywania w przestrzeni pamięci. Aktywność ta ma, jak już pisałam, charakter zmysłowy, kinestetyczny. Na poziomie założeń ekspozycja ma być (jest) współtworzona przez zwiedzających. W tym sensie jest interaktywna, że wymaga działania, by w pełni odczuć charakter rekonstruowanego tu środowiska. Cielesne zaangażowanie jest jednak zredukowane do wrażeń naskórkowych, odległych od afektywnego działania wydarzenia historycznego - w muzeum afekt staje się jedynie efektem, estetycznym impulsem, pozbawionym odesłania do emocji gwałtownych czy bardziej skomplikowanych. Ten mechanizm można oczywiście niuansować, czego przykładem takie próby,jak zderzenie perspektywy dwu ulic - „aryjskiej” i żydowskiej w Galerii Zagłady Muzeum POLIN czy umieszczenie opowieści o Irenie Sendlerowej w „kryjówce” w pierwszej wersji ekspozycji Muzeum II Wojny. Trudno jednak niuansować samozwrotny charakter samego doświadczenia muzealnego, w którym zwiedzający zawsze skupiony jest na sobie zwiedzającym - albo próbuje zobaczyć i poczuć siebie w realiach historii, albo przypomina sobie, że bolą go nogi lub plecy czy też musi do toalety. 
W skrajnym przypadku, tam, gdzie konstrukcja wystawy ma czytelnego bohatera - jak Muzeum Powstania Warszawskiego żołnierza, a ECS kogoś, kto stawia opór władzy - dokonuje się narcystyczne uwznioślenie. Na ekspozycji nie ma strachu i gniewu, jest natomiast duma i chwała - czyste uczucia i jasne wrażenia. Podmiot, który uczestniczy w podobnym doświadczeniu, odczuwa dumę nie tylko z powodu aktów przodków; zostaje uwznioślony przez swoje własne podniosłe uczucia, jest dumny z tego, że czuje dumę. Dokonuje się przejście od „oni byli bohaterami” do „jesteśmy - a w każdym razie moglibyśmy być - bohaterami".

Znów, proces ten może wzmacniać działanie pamięci jednostkowej jednak nie o wydarzeniu samym (to dotyczy jedynie części zwiedzających i niektórych wydarzeń), ale o jego medialnych zapisach i rekonstrukcjach. W ekspozycje wplatane są oczywiście materiały dokumentalne z epoki, zwykle znane już przecież skądinąd, rozpowszechniane przy okazji rocznic na przykład, ale też często fikcyjne, dokładające dodatkową warstwę do złożonej sieci znaczeń i ich mediacji. To pamięć rekonstrukcyjna i pulpowa - opiera się na odtworzeniu praktyk znanych z reprezentacji, czyli na wytwarzaniu nowych reprezentacji ${ }^{23}$ oraz na przekazie medialnym, a nie pokoleniowym.

O tym drugim pisze Marianne Hirsch, proponując pojęcie „postpamięci”, czyli pamięci wytwarzanej w efekcie przekazu rodzinnego, opartego zatem na więzi emocjonalnej, ale zarazem już z większym dystansem czasowym. Postpamięć nie opiera się zatem na przypominaniu sobie, ale na wyobrażaniu (na „inwestycji” $)^{24}$. W przypadku pulp-pamięci, z jaką mamy do czynienia współcześnie, gdy dystans pokoleniowy wobec wydarzenia jeszcze się zwiększył, ta praca wyobrażania sobie nie do końca zależy od jednostki. Wyobraźnia w tym kontekście została skanalizowana w formach ready-made pamięci (obrazy fikcyjne, popularne przedstawienia), w powszechnie rozpoznawalnych obrazach i gestach wspólnej pamięci zrekonstruowanych zgodnie z obrazami-zapisami (fotografiami i świadectwami). Jest to zatem praktykowane

23 Wychodzi zatem poza podział społeczeństw pamięci zaproponowany przez Paula Connertona na te, które pamiętają za pośrednictwem praktyk utrwalonych w zapisie (inscribing), i te, które opierają się na praktykach utrwalonych w ciele i w obyczaju (incorporating). P. Connerton /ak społeczeństwa pamiętaja, przeł. M. Napiórkowski, Wydawnictwa UW, Warszawa 2012.

"Postmemory is distinguished from memory by generational distance and from history by deep personal connection. Postmemory is a powerful and very particular form of memory precisely because its connection to its object or source is mediated not through recollection but through imaginative investment and creation". M. Hirsch Family Frames. Photography, Narrative and Postmemory, Harvard University Press, Cambridge-London 1997, s. 22. 
cieleśnie składowisko rozmaitych elementów wykorzystywanych w aktach rekonstrukcji, odtworzeń i powtórzeń, w jedno łączących fikcję i dokument, miksujących wyobrażenie (rzadziej wiedzę) o przeszłości z obrazami "pożyczonymi” z innych kontekstów i z odczuciami wyobrażającego sobie „ja”. To ciągle na nowo przemontowywane found-footage.

W muzeum jest ono częścią spektaklu i doświadczenia estetycznego w istocie nawet nie podobną do konsumpcji w swojej „niemożności użycia”, ale dokładnie, jak ona - konsumpcją.

O tej „niemożności użycia”, ściśle związanej z „umuzuealnieniem życia”, pisał Giorgio Agamben:

Duchowe potęgi określające niegdyś egzystencję człowieka - sztuka, religia, filozofia, idea natury, a nawet polityka - potulnie wycofały się, jedna po drugiej, do Muzeum. Nie chodzi tu o jakieś konkretne miejsce czy przestrzeń fizyczną, ale o oddzielony wymiar, do którego przenosimy to, czego nie uznajemy już za prawdziwe i fundamentalne. ${ }^{25}$

W tym ujęciu muzeum, wbrew intencjom jego twórców, potwierdzałoby jedynie, że tożsamościowe gry i zabawy nie mają charakteru "profanicznego", czyli w istocie sprawczego, na nowo umożliwiającego użycie. Pozostawałoaby jedynie w sferze muzealnego spektaklu bez konsekwencji dla życia, potwierdzając dominację konsumpcyjnego czy też estetycznego bodźca jako podstawowego elementu doświadczenia. (Konieczne jest jednak przypomnienie i zastrzeżenie - że mowa tu jedynie o ekspozycji, która działa w kontekście wielu innych działań muzeum, w tym różnego rodzaju praktyk edukacyjnych o różnym znaczeniu, środkach i potencjale, również być może profanicznym.)

Jest w tej układance jednak niepokojący moment związany z narcystycznym naddatkiem - czy podmiot poddany doświadczeniu tej spektakularnej kapsuły czasu, łączącej za pomocą medialnych klisz i silnych wrażeń przeszłość z dniem dzisiejszym, nie będzie jutro szukał ujścia dla tej energii? To zagrożenie nie jest oczywistym wynikiem działania muzeum, a w każdym razie nie każdego muzeum.

Wracając do metafory towarowej - niektóre bliższe są modelowi domu towarowego: „wszystko dla wszystkich”. Zakładają one z jednej strony zróżnicowanie tożsamości, wiedzy i zainteresowań odbiorców, z drugiej,

25 G. Agamben Pochwała profanacji, w: tegoż Profanacje, przeł. M. Kwaterko, PIW, Warszawa 2006, s. 106. 
w efekcie - rozpraszają przekaz, konstruują go wielowątkowo i w różnych tonacjach, niejako polifonicznie. Stocznia to krzyż i biało-czerwona flaga, ale też papierosy i program telewizyjny, życie żydowskie to religia, ale też gęś i czosnek, wymiar polityczny nakłada się na życie codzienne, a przedstawienie wydarzeń traumatycznych na obyczajowe ciekawostki. Ta możliwość „rozgęszczenia” przekazu w dużym stopniu zależy od tematu i skali ekspozycji, a nawet od wielkości przestrzeni, w której jest prezentowana.

To, co nazwałam naddatkiem narcystycznym, ma jednak swoje źródło również - a może przede wszystkim - w zdefiniowaniu estetycznego doświadczenia jako doświadczenia zbiorowego: $\mathrm{w}$ decyzji, że nie proponuje się miejsc czy punktów pozwalających na przyjęcie innej niż dominująca perspektywa, i w założeniu, że istnieje uprzywilejowana pozycja odbiorcza, którą mogą zająć jedynie przedstawiciele określonej grupy. Są wydarzenia dostępne jedynie „dzielnym Polakom” - a ekspozycja muzealna nie jest przestrzenią ich reprezentacji, ale zbiorowego performowania.

\section{Abstract}

\section{Iwona Kurz}

UNIVERSITY OF WARSAW

Narcissus at the Museum: A Postmodern Adventure

Kurz explores how historical exhibitions at narrative museums are experienced (the first one in Poland was the Warsaw Rising Museum, which opened in 2004). On the one hand she highlights the assumptions on which these exhibitions are founded, their intentional construction, the message they suggest and what reactions they anticipate on the viewers' part. On the other hand Kurz examines the mechanisms that are external to the museum's message - mechanisms related above all to the effects of the media and the logic of capitalism, which affects the work of museums and exhibitions.

\section{Keywords}

narrative museums, collective memory, Warsaw Rising Museum, museification, culture of narcissism 